УДК 338.483.13:392.72(477)

JEL Classification: F6, L26, L83

ЗЕЛЕНКО О. О. ${ }^{1}$

\title{
СУЧАСНІ ВИКЛИКИ СФЕРИ ГОСТИННОСТІ УКРАЇНИ
}

DOI: $10.32620 /$ cher.2021.2.12

Постановка проблеми. Туристична галузь та безпосередньо готельно-ресторанна сфера серед всіх секторів економіки постраждали найбільше. Таким чином, актуальним $є$ визначення поточних обставин та ефективних інструментів ії розвитку з метою повернення до передкризового стану та подальшого сталого функціонування. Мета дослідження: систематизація аналітичної інформації щодо сучасного стану сфери гостинності, визначення стратегічних пріоритетів і комплексу заходів щодо відновлення сталої діяльності та зміцнення конкурентоспроможності вітчизняної сфери гостинності на національному та міжнародному ринку. Методи дослідження: у процесі здійснення наукової роботи було використано загальнонаукові та спеціальні методи наукової абстракції, індукції та дедукції, статистичного аналізу, аналогії та кількісного і якісного порівняння. Гіпотеза дослідження: припущено, що в основу розвитку сфери гостинності, як складової туристичної індустрії має бути покладено сукупність теоретичних засад, історичних передумов та сучасних обставин розвитку підприємницької діяльності у зазначеній галузі на національному та міжнародному рівні. $B u$ клад основного матеріалу: більшість проблем національної сфери гостинності мають застарілий характер; сучасні умови діяльності підприємств сфери гостинності формуються під впливом факторів (пандемія, глобальна інформатизація, зміна конкурентних детермінант та поглиблення спеціалізаціï); стратегічні пріоритети розвитку сфери гостинності передбачають концентрацію зусиль щодо: захисту власних інтересів шляхом приєднання до відповідних професійних об'єднань, інформатизації всіх напрямів роботи, активної співпраці із ЗВО та екологізації об'єктів і всього спектру послуг, що пропонуються клієнтам. Оригінальність та практична значимість дослідження: представлені у дослідженні результати актуальні для врахування та практичного впровадження для будь-якого підприємства сфери гостинності України. Висновки та перспективи подальших досліджень. Дотримання представлених рекомендацій дасть змогу підприємствам гостинності втриматися на регіональних та вітчизняному туристичному ринку, зміцнити власну конкурентоспроможність та запропонувати послуги належної якості не тільки внутрішнім, але й іноземним туристам.

Ключові слова:

сфера гостинності, проблеми, фактори, стратегічні пріоритети, криза, конкурентоспроможність.

\section{MODERN CHALLENGES OF THE HOSPITALITY SPHERE OF UKRAINE}

Problem statement. The tourism industry and the hotel and restaurant sector have suffered the most among all sectors of the economy. Thus, it is important to determine the current circumstances and effective tools for its development in order to return to the pre-crisis state and further sustainable operation. The purpose of the study. Systematization of analytical information on the current state of the hospitality industry, determination of strategic priorities and a set of measures to restore sustainable activities and strengthen the competitiveness of the domestic hospitality industry in the national and international market. Research methods. In the process of scientific work were used general and special methods of scientific abstraction, induction and deduction, statistical analysis, analogy and quantitative and qualitative comparison. Research hypothesis. It is assumed that the development of hospitality as a component of the tourism industry should be based on a set of theoretical principles, historical background and current circumstances of business development in this area at the national and international levels. Presentation of the main material. Most of the problems of the national hospitality sector are outdated; modern conditions of activity of hospitality enterprises are formed under the influence of factors (pandemic, global informatization, change of competitive

1 Зеленко Олена Олександрівна, д-р екон. наук, професор кафедри «Міжнародна економіка і туризм», Східноукраїнський національний університет імені Володимира Даля, м. Сєвєродонецьк, Україна.

Zelenko Olena, Doctor of Economic Science, Professor of International Economics and Tourism Department, Volodymyr Dahl East Ukrainian National University, Severodonetsk, Ukraine.

ORCID ID: 0000-0003-4880-246X

e-mail: zelenko.olena@gmail.com 
determinants and deepening of specialization); the strategic priorities for the development of the hospitality sector include the concentration of efforts to: protect their own interests by joining the relevant professional associations, informatization of all areas of work, active cooperation with institutions of higher education and greening of facilities and services offered to customers. Originality and practical significance of the study: the results presented in the study are relevant for consideration and practical implementation for any enterprise in the hospitality industry of Ukraine. Conclusions and prospects for further research. Compliance with the recommendations will allow hospitality companies to stay in the regional and domestic tourism market, strengthen their competitiveness and offer services of good quality not only domestic but also foreign tourists.

Key word:

hospitality, problems, factors, strategic priorities, crisis, competitiveness.

\section{СОВРЕМЕННЫЕ ВЫЗОВЫ СФЕРЫ ГОСТЕПРИИМСТВА УКРАИНЫ}

Постановка проблемы. Туристическая отрасль и непосредственно гостинично-ресторанное сфера среди всех секторов экономики пострадали больше всего. Таким образом, актуальным является определение текущих обстоятельств и эффективных инструментов ее развития с целью возвращения к предкризисному состоянию и для дальнейшего устойчивого функционирования. Цель исследования: систематизация аналитической информации о современном состоянии сферы гостеприимства, определение стратегических приоритетов и комплекса мероприятий по восстановлению устойчивой деятельности и укреплению конкурентоспособности отечественной сферы гостеприимства на национальном и международном рынке. Методы исследования. В процессе осуществления научной работы были использованы общенаучные и специальные методы научной абстракции, индукции и дедукции, статистического анализа, аналогии, количественного и качественного сравнения. Гипотеза исследования. Предположено, что в основу развития сферы гостеприимства, как составляющей туристической индустрии, должен быть положены совокупность теоретических основ, исторических предпосылок и современных обстоятельств развития предпринимательской деятельности в указанной области на национальном и международном уровне. Изложение основного материала. Большинство проблем национальной сферы гостеприимства имеют устаревший характер; современные условия деятельности предприятий сферы гостеприимства формируются под влиянием факторов (пандемия, глобальная информатизация, изменение конкурентных детерминант и углубление специализации); стратегические приоритеты развития сферы гостеприимства предусматривают концентрацию усилий по: защите собственных интересов путем присоединения к соответствующим профессиональным объединениям, информатизации всех направлений работы, активизации сотрудничества с ВУЗами и экологизации объектов, а также всего спектра услуг, предлагаемых клиентам. Оригинальность и практическая значимость исследования. Представлены в исследовании результаты актуальны для учета и практического внедрения любому предприятию сферы гостеприимства Украины. Bыводы и перспективы дальнейших исследований. Соблюдение представленных рекомендаций позволит предприятиям гостеприимства удержаться на региональных и отечественном туристическом рынке, укрепить собственную конкурентоспособность и предложить услуги надлежащего качества не только внутренним, но и иностранным туристам.

\section{Ключевые слова:}

сфера гостеприимства, проблемы, факторы, стратегические приоритеты, кризис, конкурентоспособность.

Постановка проблеми. Поточні обставини функціонування туристичної галузі та готельно-ресторанної сфери країни обумовлені цілим спектром передумов та чинників, що здійснюють вплив на соціальноекономічне середовище загалом та сферу гостинності, зокрема.

Розвиток туризму в Україні тривалий час мав позитивну динаміку: спостерігалося зростання туристичних потоків, відкривалися нові заклади розміщення та підприємства ресторанного господарства; розпочато процес формування нових туристичних дестинацій. Звичайно, як і вся національна економічна система із втратами переживала всі кризи, зокрема, світову фінансову 2008-2009, та національну політичну 2013-2014, результатом якої стали: різкий спад кількості іноземних відвідувачів, значне скорочення внутрішніх туристів, втрата частини підприємств 3 причини припинення їх діяльності через втрату клієнтів, або 3 причини територіального їх розташування на окупованих територіях. 
У даний час сфера гостинності переживає ще одну кризу пов'язану з поточною ситуацією у глобальних масштабах, викликаною всесвітньою пандемією через новий віpyc COVID-19. Саме туристична галузь та безпосередньо готельно-ресторанна сфера серед всіх секторів економіки постраждали найбільше. Отже, актуальним $є$ визначення поточних обставин та ефективних інструментів іiі розвитку з метою повернення до передкризового стану та подальшого сталого функціонування.

Аналіз останніх досліджень і публікацій. Проблемами розвитку сфери гостинності опікується велика кількість вітчизняних науковців. Серед останніх найбільшу увагу привертають роботи Т. Чаркіної, Л. Марценюка, В. Задоя, О. Пікуліної [1], О. Жегус, О. Ілляшенка [2], Ю. Шевчук [3], О. Графської [4], Г. Тарасюка, А. Чагайди та I. Соколовської [5] тощо.

Так, Т. Чаркіна, Л. Марценюк, В. Задоя та О. Пікуліна [1] підкреслюючи цілу низку негативних явищ у сучасній готельноресторанній, серед яких основна, це скорочення штату працівників, наголошують на необхідності використання довгострокового планування із врахуванням нових обмежень, пов'язаних із карантинними нормами.

О. Жегус, О. Ілляшенко [2] серед усіх факторів успішності готельно-ресторанної сфери виділяють лояльність клієнтів, пропонуючи оцінювати іiі за допомогою 5-ти бальної шкали, та розрахунку у подальшому індексу лояльності.

Ю. Шевчук [3] наполягає на пошуку нових системних державних механізмів реформування галузі на основі концепції сталого управління 3 метою протистояння умовам мінливого середовища.

Натомість, Г. Тарасюк, А. Чагайда та I. Соколовська [5] вважають, що ключовою перевагою має стати нестандартна пропозиція від закладів розміщення та харчування. Зокрема, на думку науковців, туристи віддаватимуть перевагу закладам, що піклуються про оточуюче середовище.

О. Графська [4], досліджуючи тренди розвитку не тільки сфери гостинності але й всієї туристично-рекреаційної галузі, відзначає провідну роль інформаційних технологій, вважаючи, що саме це $\epsilon$ основним інструментом, який дозолить втриматися «на плаву» українським провайдерам туристичних послуг та послуг гостинності.
За останній рік з'явилась велика кількість публікацій щодо аналізу кризи 2020 та великої кількості варіантів виходу 3 неї. Більшість авторів фокусують увагу на одній групі проблем та пропонують певні заходи щодо їх вирішення. Але, як правило, проблеми мають системний характер, виникають неодночасно, тому $є$ необхідність поглянути на ситуацію поточної кризи комплексно; визначити стратегічні пріоритети для подальшого відновлення та розвитку сфери гостинності України.

Мета статті. Систематизація аналітичної інформації щодо сучасного стану сфери гостинності, визначення стратегічних пріоритетів і комплексу заходів щодо відновлення сталої діяльності та зміцнення конкурентоспроможності вітчизняної сфери гостинності на національному та міжнародному ринку туристичних послуг.

Виклад основного матеріалу дослідження. Цікавість до ситуації, що склалася в готельно-ресторанній сфері, обгрунтована не тільки поточним станом та превалюванням кризових явищ. Готельно-ресторанна сфера України, переживши кризу 2008-2009 рр. 3 гідністю перенесла випробування Свро-2012, хоча на той час підприємства цього сектору економіки за загальним фінансовим результатам були збитковими (таблиця 1).

Відповідно до даних табл. 1. станом на 2013 рік, готельна індустрія та сфера послуг ресторанного господарства України також переживали складний період. Серед основних негативних тенденцій того часу [7]:

- низький рівень завантаженості закладів розміщення та підприємств ресторанної сфери (у середньому тільки на $30 \%$ );

- невідповідність пропозиції готельних послуг реальним потребам ринку: замість введення в експлуатацію готельних та ресторанних підприємств бюджетного та середнього класу пропонуються заклади для категорії VIP клієнтів;

- диспропорції у ціновій політиці та якості обслуговування: ціна послуг на ринку України вища ніж у провідних туристичних європейських державах, але якість обслуговування навпаки - набагато нижча;

- збитковість підприємств сфери гостинності, що підтверджується сталою негативною динамікою: з 2010 по 2013 р. готельні підприємства збільшили свої збитки майже в 4 рази, ресторанні заклади - майже в 2 рази; 
Таблиця 1: Фінансовий результат діяльності підприємств сфери гостинності до оподаткування

\begin{tabular}{|c|c|c|}
\hline \multirow{2}{*}{ Роки } & $\begin{array}{c}\text { Заклади тимчасового роз- } \\
\text { міщення }\end{array}$ & $\begin{array}{c}\text { Заклади послуг ресторанного го- } \\
\text { сподарства }\end{array}$ \\
\cline { 2 - 4 } & тис. грн. & тис. грн \\
\hline 2010 & $-187376,0$ & $-248627,4$ \\
\hline 2011 & $-208680,1$ & $-234572,3$ \\
\hline 2012 & $-601480,6$ & $-164138,4$ \\
\hline 2013 & $-724010,5$ & $-412604,2$ \\
\hline 2014 & $-5118590,2$ & $-1239341,6$ \\
\hline 2015 & $-5243358,3$ & $-1736967,5$ \\
\hline 2016 & $-2124046,6$ & 206260,0 \\
\hline 2017 & 1463132,0 & 659959,1 \\
\hline 2018 & 2158170,2 & \\
\hline 2019 & 3307113,2 & \\
\hline 2020 & \multicolumn{2}{|c|}{$-5004000,6$} \\
\hline
\end{tabular}

у 2014 році $з$ причини виникнення воєннополітичного конфлікту заклади розміщення погіршили свої результати діяльності більше ніж у 7 разів підприємства ресторанного господарства - відповідно у 4 рази; найгірша ситуація постерігалася на сході України [8], де фінансові проблеми посилювалися негативним ставленням до регіону як до небезпечної для подорожей території.

Три роки фінансової стабільності з 2017 по 2019 pp. (табл. 1.) і у 2020 готельноресторанні підприємства знову стають збитковими. Поточна ситуація та перспективи даного сектору економіки схематично представлені на рис. 1, який презентує три аспекти сьогодення сфери гостинності: проблеми, фактори та стратегічні пріоритети подальшого розвитку. Детальну характеристику варто розпочати саме $з$ проблем.

Bci зазначені на рис. 1 проблеми, мають довге коріння, вони не 3'явилися 1-2 роки томy, a їх ігнорування призвело до загострення ситуації в галузі під час карантинних обмежень. Тінізація сфери гостинності: ця проблема у тій чи іншій мірі існувала завжди, але отримала масштабний розвиток з 2014 року, коли прихильники відпочинку на Кримському узбережжі втратили таку можливість та почали шукати альтернативні варіанти в межах підконтрольної частини України. Всі домогосподарства узбережжя Чорного та Азовського моря стали потенційними провайдерами послуг гостинності, і ті хто зорієнтувався - спробували задовольнити наявний попит, без реєстрації підприємницької діяльності. Друга хвиля активної тінізації сектору відбулася 2020, коли приблизно 35\% закладів гос- тинності офіційно припинили свою роботу [3, c. 44], а частина тих, хто бажав вижити, скорочували персонал, та переєструвались як фізичні особи-підприємці, пропонуючи своїм підлеглим отримувати зарплату «в конвертах». Нова хвиля реальних «тіньовиків» у 2020 також виникнула на Азовському узбережжі Донецької області, куди, аби не ризикувати в умовах пандемії, поїхали всі бюджетні відпочивальники Донецької та Луганської області. Побоюючись невдалої спроби, далеко не всі легально оформили свій бізнес.

Низька якість проєктних робіт - цю проблему варто зазначити як одну із найбільш глобальних, що останнім часом тільки загостюється. Прикладів такого недолугого проєктування та видачі дозвільних документів на будівництво дуже багато. Показовим $\epsilon$ узбережжя Одеської області, яке постійно страждає від підтоплення та зсувів, внаслідок чого руйнуються берегові території та будівлі як житлових, так і туристичних комплексів. Така сама загроза руйнування та знищення майна не тільки власників закладів розміщення, але й туристів існує у Кирилівці Запорізької області, де відбувається забудова на потенційно-небезпечних ділянках морського узбережжя. Вже два роки поспіль (2020-2021 pp.) це курортне містечко вимушене боротися iз наслідками водної стихії, витрачаючи кошти на відновлення інфраструктури замість того, щоб укріпити берегову лінію, побудувати хвилерізи та прискіпливіше розглядати проєкти нових забудов. Інша проблема проєктної роботи - знання основоположних норм будівництва, зокрема, обов'язкове планування дренажної та водостічної системи. 


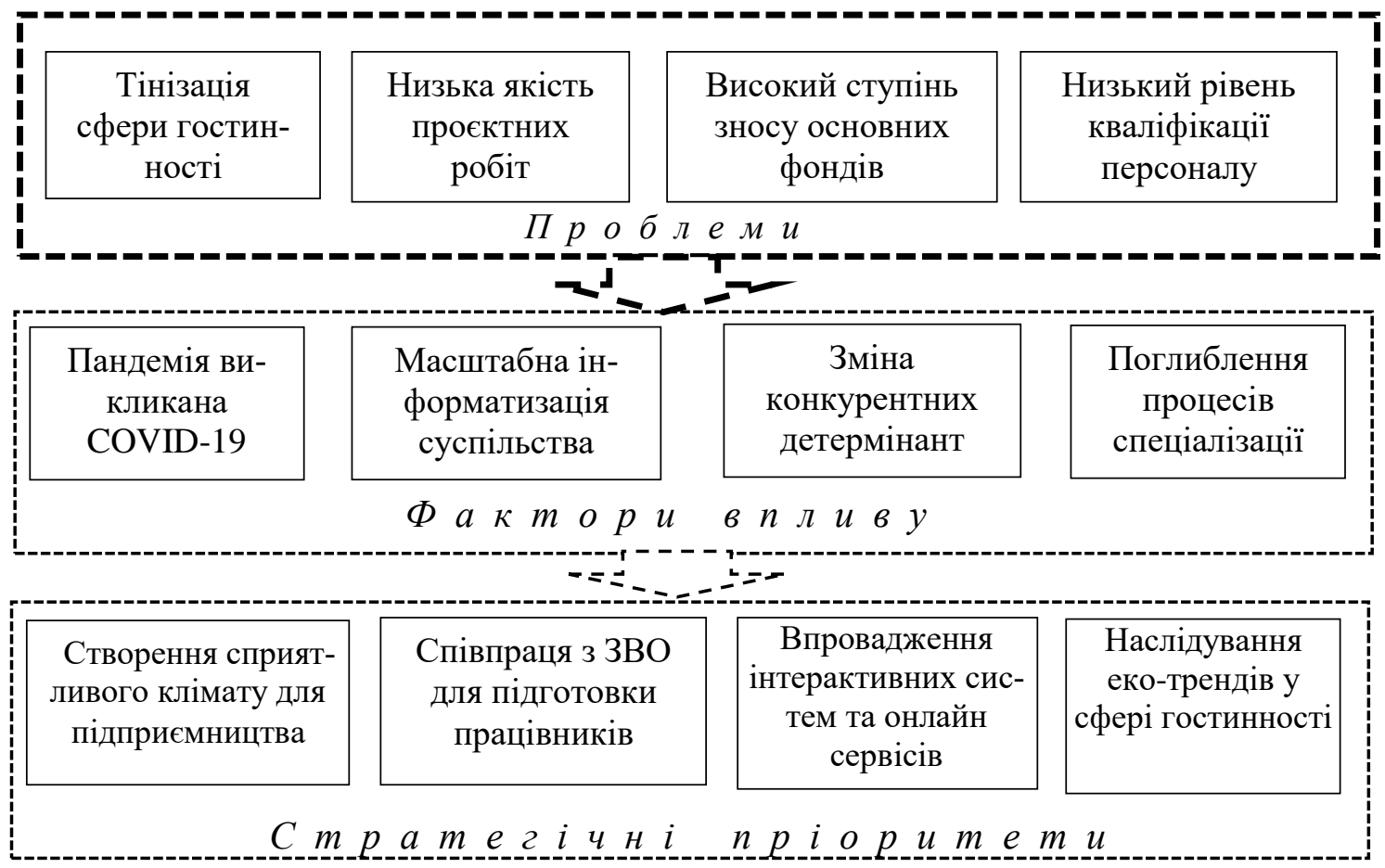

Рисунок 1 - Сучасний стан та стратегічні пріоритети розвитку сфери гостинності України Джерело: сформовано автором на підставі [3]

Про Одесу вже не говоримо - це проблема старого міста, але неможна не пригадати селище Коблево, яке у туристичний сезон 2021 через великі зливи періодично перетворювалося у Вилкове (український аналог італійського міста на воді). Страждали найбільш дороговартісні заклади розміщення та ресторанні підприємства, розташовані на першій чи другій береговій лінії, їх перші поверхи були підтоплені до рівня 0,3-0,5 м в залежності від місця розташування об'єкту.

Наступна проблема - великий ступінь зносу основних фондів. Від неї страждають навіть всесвітньо-відомі українські курорти, зокрема, такі як Трускавець, який за часів підпорядкування Польщі був дуже популярний, але обмежений із доступом тільки для заможних туристів, спроможних сплатити за дороговартісні послуги курорту [9]. За радянських часів у обслуговування основних фондів здравниці майже нічого не вкладалося i результат: верхній бювет зачинено; він, за відсутності капітальних вкладень, перебуває у аварійному стані. I таких прикладів можна наводити безліч. Більшість закладів гостинності Луганської та Донецької області, що не працюють, призупинили свою роботу, саме через високий ступінь зносу та аварійний стан основних фондів.
Низький рівень кваліфікації персоналу - ще одна гостра проблема сфери гостинності. Висловлюючись словами відомого прислів'я, варто підкреслити, що саме «кадри вирішують все», а не фінансові ресурси, чи їх відсутність. Говорячи про кадри, маємо на увазі не тільки обслуговуючий персонал, але й рівень кваліфікації середнього і топ-менеджменту. Незважаючи, на той факт, що фахівців 3 готельно-ресторанної справи в України готують вже більше 20 років, якість сервісу та управління в сфері гостинності залишаються на рівні «нижче середнього». Особливо гостро ця проблема проявляється у високий туристичний сезон, коли спостерігається великий попит та винаймаються сезонні працівники, що взагалі не маю жодної професійної освіти відповідного спрямування.

На наявні проблеми розвитку сфери гостинності України накладається вплив цілої низки поточних факторів. Серед представлених на рис. 1, найбільш проблемним фактором $\epsilon$ всесвітня пандемія, що виникла в результаті появи нового вірусу Covid-19. Саме сфера гостинності постраждала найбільше, адже на іiі діяльність було покладено найжорсткіші обмеження. Тривалий час готелі взагалі не приймали відвідувачів; ресторани працювали тальки «на виніс». Але така ситуація примусила власників критично поглянути на 
діяльність свого закладу. Зокрема ресторани класу «люкс» переорієнтувались на споживачів із середнім рівнем достатку та стали здійснювати доставку їжі в офісні центри. Деякі представники малого бізнесу в сфері ресторанного господарства, аби вижити, взагалі відмовились від оренди приміщень та виконують замовлення клієнтів за місцем свого постійного проживання.

Масштабна інформатизація суспільства - ще один фактор, вплив якого сфера гостинності значно відчувала і до 2020, але пандемія та карантинні обмеження прискорили процес інформатизації у декілька разів, а ті провайдери послуг гостинності, які ставили собі за мету «вижити» під час карантину, були вимушені опановувати новітні технології обслуговування та засоби комунікації, що дозволяють мінімізувати особисті контакти між провайдером та споживачем послуги.

Зміна конкурентних детермінант - фактор, який впливаючи на сучасну сферу гостинності, передбачає зміщення фокусу уваги і у власників закладів і у самих клієнтів 3 конкурентних переваг суто вартісного характеру на переваги якісного обслуговування. Український турист навіть за умови обмеженого бюджету воліє отримати якісніші послуги, тому прискіпливо порівнює можливості, які пропонують підприємства сфери гостинності за ті самі кошти. Крім того у складі даного фактору варто враховувати зміну стилю життя більшості потенційних туристів та їх страхи, пов'язані з пандемією, які впливають на остаточне рішення, щодо обрання закладу гостинності [2, с. 120].

Поглиблення спеціалізації закладів гостинності - це останній фактор, який є наслідком попереднього, такий підхід дозволяє провайдерам сконцентруватися на уособленій цільовій аудиторії, вдосконалювати свої послуги, аби відповідати ії вимогам та зберегти свою позицію на ринку.

Представлені проблеми та фактори функціонування сфери гостинності в сучасних умовах дозволяють визначити стратегічні пріоритети розвитку даного сектору вітчизняної економіки.

Створення сприятливого клімату для розвитку підприємництва. Важко говорити про виконання даного стратегічного пріоритету в умовах світової пандемічної кризи. Уряд країни, здійснює певні кроки для підтримки малого та середнього бізнесу під час карантинних обмежень, зокрема [10]: кредитні канікули; податкові преференції; виплата допомоги по частковому безробіттю; інформаційна підтримка бізнесу, яка передбачає спрощення реєстраційних та погоджувальних процедур через їх інформатизацію та переведення процесів в онлайн режим.

Всі представлені заходи так чи інакше реалізуються урядом, хоча є дуже велика кількість нарікань 3 боку самих підприємців щодо їх несвоєчасності введення, несистемності, недостатності, тощо. Альтернативний шлях - це об'єднання зусиль на місцях та приєднання до регіональних туристичних асоціацій, або інших громадських організацій (які співпрацюють 3 асоціацією «Національна туристична організація України», ГО «Асоціацією індустрії гостинності України»), покликаних захищати фінансово-економічні інтереси регіону, як туристичної дестинації, лобіювати їх на національному рівні, просувати власні регіональні бренди на національний та міжнародний ринок.

Співпраця з 3ВО для підготовки кваліфікованих працівників - ще один стратегічний пріоритет. Даний напрям діяльності вже давно пропагується, як один із ефективних напрямів перспективної професійної співпраці для підготовки майбутніх фахівців, які цілеспрямовано будуть працевлаштовуватися на конкретних підприємствах-замовниках кадрів. Нажаль, не всі підприємці сфери гостинності розуміють перспективність такої співпраці, зокрема, така проблема спостерігається у східних регіонах (зокрема у Луганській області): потенційні роботодавці не бажають витрачати свій час та заключати угоди 3 приводу надання бази практики майбутнім фахівцям. Але переваги такої співпраці ще 6 років тому визнали представники сфери гостинності Одеси, які не тільки надавали базу практики, але й здійснювали технічну підтримку ЗВО щодо надання спеціалізованої оргтехніки та програмного забезпечення. В результаті, здобувачі вищої освіти вже 33 курсу паралельно із навчанням гарантовано мали місце працевлаштування, а роботодавець отримував молодого фахівця із потрібним набором професійних компетентностей.

Впровадження інтерактивних систем та онлайн сервісів - ще один стратегічний пріоритет. Як правило, у даному стратегічному напрямку розвитку варто розглядати два основних напрямки роботи: інформатизація внутрішніх процесів управління закладом; інформатизація комунікаційних процесів із зовнішнім середовищем. В число основних функцій, які повинні бути присутніми в ав- 
томатизованих системах управління підприємствами готельної індустрії, входять наступні: управління бронюванням; управління номерним фондом; управління бухгалтерією; управління клієнтами; адміністрування. Зовнішні комунікації передбачають активну роботу по просуванню послуг підприємства у онлайн середовищі: в онлайн месенджерах, у соціальних мережах, на туристичних сайтахконсолідаторах, 3 розробниками мобільних туристичних додатків, тощо. Цей процес розпочато задовго до 2020, але потреба мінімізувати особисті контакти пришвидшила темпи впровадження даних інструментів комунікації, відмова від їх використання гарантовано призведе до закриття бізнесу. Ці рекомендації підтверджуються проведеним соціологічним дослідженням, за результатами якого більше 30\% подорожуючих здійснюють процес планування власної подорожі суто через онлайн засоби без особистого контакту із провайдерами послуг. А, враховуючи той факт, що 48\% подорожуючих - це молодь у віці від 18 до 29 років - частка таких інформаційно обізнаних туристів тільки зростатиме [5, с. 19].

Наслідування еко-трендів у сфері гостинності - останній важливий стратегічний пріоритет. Розвиток міжнародного туризму, разом із економічними вигодами, залишав негативний слід на стані навколишнього середовища: знищення заповідних територій заради будівництва нових готельних комплексів; забруднення природно-рекреаційних ресурсів продуктами та відходами життєдіяльності людини у місцях скупчення туристів. У урбаністиці навіть виникнуло нове поняття «овертуризм», тобто перенасиченість міста туристичним потоком: ситуація, у якій бажання заробити превалює над принципами сталого розвитку і нехтуються норми ємності території щодо можливості прийняти та якісно обслужити максимально-допустиму кількість туристів. Саме таке явище останні роки можна було спостерігати у найбільших містах, які є світовими туристичними центрами; що дуже шкодило навколишньому середовищу, обмежувало можливості екосистеми до регенерації та відновлення. Жорсткий карантин наочно продемонстрував швидкі темпи відновлення природно-рекреаційних ресурсів: зниження рівня забруднення повітря, покращення хімічного складу води міських водойм та річок, відновлення їх флори і фауни. Всі ці еко-маркери та потреба дистанціюватись змінюють уподобання туристів, спрямовуючи увагу на екзотичні пропозиції від закладів гостинності, які мають еко-спрямований характер діяльності. Агроготелі, глемпінги, екобази - це саме ті варіанти розміщення, які привертають увагу соціально-відповідальних туристів. За останніми опитуваннями $76 \%$ туристів [5, с. 21] відходять від нераціонального споживання та необгрунтованих витрат під час відпочинку. Більшість замість інертного гламурного комфорту надає перевагу отриманню знань та вражень від нових видів активності: проживання у закладі, побудованому з еко-матеріалів та з природними відновлювальними джерелами енергії (електроенергія від вітряків чи сонячних батарей; гаряча вода, що гріється від сонячного тепла), вирощування сільськогосподарських культур та приготування 3 них автентичних страв даної місцевосі, еко-похід з метою очищення земельних ділянок та русла річок. Цей перелік можна продовжувати.

Висновки та перспективи подальших досліджень. Сучасна сфера гостинності перебуває на стадії радикальних трансформаційних змін. Вітчизняні підприємства готельно-ресторанної сфери не $є$ виключенням. У ході дослідження визначено:

- більшість проблем національної сфери гостинності мають застарілий характер та залишаються без уваги провайдерів послуг більше 10 років поспіль, серед них: тінізація економічних взаємовідносин, низька кваліфікація працівників галузі та незадовільна якість проєктних робіт; високий ступінь зносу основних фондів;

- сучасні умови діяльності підприємств сфери гостинності формуються під впливом декількох факторів (пандемія, глобальна інформатизація суспільства, зміна конкурентних детермінант та поглиблення спеціалізації в галузі) врахування яких є обов'язковим для кожного провайдера готельно-ресторанних послуг;

- стратегічні пріоритети розвитку сфери гостинності передбачають концентрацію зусиль щодо: захисту власних інтересів шляхом приєднання до відповідних професійних об'єднань, інформатизації всіх напрямів роботи, активної співпраці із ЗВО та екологізації об'єктів і всього спектру послуг, що пропонуються клієнтам.

Дотримання представлених рекомендацій дасть змогу підприємствам гостинності втриматися на регіональних та вітчизняному туристичному ринку, зміцнити власну конкурентоспроможність та запропонувати послу- 
ги належної якості не тільки внутрішнім, але й іноземним туристам.

\section{Література}

1. Чаркіна Т. Ю., Марценюк А. В., Задоя В. О., Пікуліна О. В. Стратегічні напрями управління готельно-ресторанним бізнесом в умовах кризи. Економіка та держава. Серія: Економічні науки. 2021. № 2. С. 19-23.

2. Жегус О. В., Ілляшенко О. В. Управління лояльністю клієнтів у закладах готельноресторанного господарства в умовах нових викликів. Проблеми економіки. 2020. №3 (45). С. $118-125$.

3. Шевчук Ю. Сучасний стан та перспективи розвитку готельного бізнесу України: чинники та проблеми. Вісник КНУТД. Серія: Економічні науки. 2020. № 1. С. 41-51.

4. Графська О. I. Сучасні виклики та мегатренди розвитку туристично-рекреаційної сфери. Проблеми економіки. 2020. №2 (44). С. 17-23.

5. Тарасюк Г. М., Чагайда А. О., Соколловська I. О. Перспективні напрями розвитку готельного бізнесу для забезпечення фінансової стабільності індустрії гостинності України. Причорноморські економічні студії. 2020. № 55-2. C. 17-24.

6. Державна служба статистики України. Діяльність підприємств. [Електронний реcypc]. URL: http://www.ukrstat.gov.ua/

7. Зеленко О. О. Габараєва К. Р. Сучасні тенденції розвитку готельного господарства в Україні. Наукові вісті Далівського універсиmетy. 2013. № 10. [Електронний ресурс]. URL: http://nbuv.gov.ua/UJRN/Nvdu_2013_10_6

8. Зеленко О. О. Перспективи розвитку туризму Луганщини в умовах воєннополітичної нестабільності. Науковий вісник Мукачевського державного університету. Економічні науки. 2015. Вип. 2(4). Ч. 2. С. 138-143.

9. Колгушева О. Нашому курорту потрібен статус державного, але не просто "дощечка золота", а захист і можливості. Укрінформ. 2020. 29 вересня. [Електронний ресурс]. URL: https://www.ukrinform.ua/rubric-regions/3108487andrij-kulcinskij-miskij-golova-truskavca.html

10. Програми підтримки бізнесу. Коронавірус в Україні. Офіційний портал міністерства охорони здоров'я. [Електронний ресурс].

\footnotetext{
Стаття надійшла

до редакції : $15.04 .2021 \mathrm{p}$.
}

URL: https://covid19.gov.ua/prohramy-pidtrymkybiznesu

\section{Reference}

1. Charkina, T. Y.., Martsenyuk, A. V., Zadoya, V. O. and Pikulina, O. V. (2021). Strategic directions of hotel and restaurant business management in crisis. Economy and state. Series: Economic Sciences, 2, 19-23.

2. Zhegus, O. V., Ilyashenko, O. V. (2020). Customer loyalty management in hotels and restaurants in the face of new challenges. Problems of economics, 3(45), 118-125.

3. Shevchuk, Y. (2020). Current state and prospects of hotel business development in Ukraine: factors and problems. Bulletin of KNUTD. Series: Economic Sciences, 1, 41-51.

4. Grafska, O. I. (2020). Modern challenges and megatrends of tourist and recreational development sphere. Problems of the economy, 2 (44), 17-23.

5. Tarasyuk, G. M., Chagaida, A. A., and Sokollovskaya, I. O. (2020). Perspective directions of hotel business development to ensure the financial stability of the hospitality industry of Ukraine. Black Sea Economic Studies, 55-2, 17-24.

6. State Statistics Service of Ukraine. (2021). Activities of enterprises. Retrieved from: http://www.ukrstat.gov.ua/operativ/menu/menu_u/ sze_20.htm

7. Zelenko, O. O., Gabaraeva, K. R. (2013). Modern trends in the hotel industry in Ukraine. Scientific news of Dahl University, 10. Retrieved http://nbuv.gov.ua/Nvdu_2013_10_6

8. Zelenko, O. O. (2015). Prospects for the development of tourism in Luhansk region in conditions of military and political instability. Scientific Bulletin of Mukachevo State University. Series: Economic Sciences, 2 (4), 2, 138-143.

9. Kolgusheva, O. (2020). Our resort needs the status of the state, but not just a "gold plate", but protection and opportunities. Ukrinform. September 29. Retrieved from: https://www.ukrinform.ua/rubric-regions/3108487andrij-kulcinskij-miskij-golova-truskavca.html

10. Business support programs. (2021). Coronavirus in Ukraine. Official portal of the Ministry of Health. Retrieved from: https://covid19.gov.ua/prohramy-pidtrymky-biznsu

Стаття прийнята

до друку: 30.06.2021 p.

Бібліографічний опис для цитування :

Зеленко О. О. Сучасні виклики сфери гостинності України / О. О. Зеленко // Часопис економічних реформ. - 2021. - № 2 (42). - С. 94-101. 